\title{
EXAMINING THE RELATIONSHIP BETWEEN BUILDING INFORMATION MODELLING (BIM) AND GREEN STAR
}

\author{
Dat Tien Doan ${ }^{1 *}$, Ali Ghaffarianhoseini ${ }^{1}$, Nicola Naismith ${ }^{1}$, Tongrui Zhang ${ }^{1}$, John Tookey ${ }^{1}$, \\ Amirhosein Ghaffarianhoseini ${ }^{1}$ \\ ${ }^{1}$ Department of Built Environment, Auckland University of Technology, 55 Wellesley St E, Auckland, \\ 1010, New Zealand
}

(Received: June 2018 / Revised: August 2018 / Accepted: December 2018)

\begin{abstract}
Neither Building Information Modelling (BIM) nor Green Star certification has yet to be widely adopted in the New Zealand construction industry. This paper, therefore, aims to encourage their development by examining the relationship between BIM adoption and Green Star certification. The qualitative approach using 21 semi-structured interviews with the construction professionals was conducted. The results indicate that despite the absence of a direct link, integrating BIM with Green Star has the potential to accelerate the Green Star uptake in New Zealand. However, BIM and Green Star uptake have two separated processes along with the lack of client demand for either BIM or Green Star projects were identified as the significant barriers to the integration. Among eight solutions recommended from the interviewees, providing education and training in both BIM and Green Star for clients and construction practitioners plays a key role. This research contributes to the current knowledge of BIM and Green Star in New Zealand by providing baseline information to the NZGBC, construction stakeholders, and the government that allows for the formulation of effective strategies to be used to develop both BIM and Green Star.
\end{abstract}

Keywords: $\quad$ BIM; Green Star; New Zealand; New Zealand Green Building Council (NZGBC)

\section{INTRODUCTION}

The use of Building Information Modelling (BIM) is still in its early stages in the New Zealand construction industry (Ghaffarianhoseini et al., 2017), while Green Star New Zealand, a relatively new system released recently by the New Zealand Green Building Council (NZGBC) to evaluate the sustainability of the projects, boasts a modest number of Green Star certified projects (Doan et al., 2017). However, BIM has rapidly adopted globally due to its widely recognized benefits, which have the potential to transform the industry during the entire lifecycle of projects (Ghaffarianhoseini et al., 2017). Bryde et al (2013) identified numerous benefits of BIM using 35 cases in eight different countries. Meanwhile, the substantial advantages of green building assessments include minimizing the impact of construction projects on the environment (Doan et al., 2017). To encourage the development of both BIM and Green Star in New Zealand, Ghaffarianhoseini et al. (2017) examined the relationship between BIM and Green Star. This research, however, concentrated on the existing literature regarding the development of a BIM-Green Star framework. This paper uses the perspectives of experts in the industry to determine whether a link between BIM and Green Star could be

\footnotetext{
*Corresponding author's email: dat.doan@aut.ac.nz, Tel. +64-210-8235489

Permalink/DOI: https://doi.org/10.14716/ijtech.v9i7.2520
} 
created. The barriers to such a connection are identified and suggestions from experts on how to overcome such problems provided. The NZGBC, construction stakeholders, and the government could use this baseline information to formulate effective strategies for the development of both BIM and Green Star.

\section{METHODS}

To provide "deep, rich observational data" for the research (Sieber, 1973; Onwuegbuzie \& Leech, 2005), a qualitative approach was adopted. Semi-structured interviews, allowing respondents the freedom to actively engage in sharing their views on their own terms (Cohen \& Crabtree, 2006; Harrell \& Bradley, 2009), were conducted with experts in the New Zealand construction industry. Owing to the shortage of specialists in both BIM and Green Star, a combination of two sampling methods was utilized: purposive sampling and snowball sampling. While the first could ensure the characteristics of the participants, potentially informative interviewees could be located using snowball sampling. LinkedIn, a powerful professional networking tool with a large database of business professionals (Albrecht, 2011; Schneiderman, 2016), was used to find initial interviewees that satisfied two criteria: (1) working in the construction for at least five years; and (2) participating in either BIM projects or Green Star projects (including Building Research Establishment Environmental Assessment Method (BREEAM) or Leadership in Energy \& Environmental Design (LEED)). The initial group of interviewees then suggested potential participants. In total, 22 interviews were carried out, 19 face-to-face and three by telephone. This sample size is considered appropriate for the qualitative approach by many researchers. For example, Galvin (2015) indicated that 12 interviews are sufficed to achieve saturation, while 20 or $15 \pm 10$ interviewees are adequate based on Crouch and McKenzie (2006) and Kvale and Brinkmann (2009), respectively. Similar sample sizes were used in previous publications in the construction area such as Hurlimann et al. (2018) and Sacilotto and Loosemore (2018). It is noted that interviews \#6, \#12, \#13, and \#20 have two interviewees for each based on the request of the corresponding interviewees.

Before conducting the interviews, approval was sought from the Auckland University of Technology Ethics Committee (2018) "to ensure that the privacy, safety, health, social sensitivities and welfare of human participants are adequately protected."

The demographics of the participants reveal different levels of experience, various types of companies, and participation in a number of either BIM or Green Star projects (see Table 1). This could enhance transferability of the results to readers for their applications, a characteristic that may promote the validity and reliability of the findings (Merriam \& Tisdell, 2016). Adequate engagement was also planned and carried out to ensure sufficient time spent on the data collection to achieve saturation (Merriam \& Tisdell, 2016). The transcripts were checked to avoid mistakes during the transcribing stage (Creswell, 2014). Finally, multiple sources of data were employed to confirm the findings, known as the triangulation method (Merriam \& Tisdell, 2016).

Transcript \#9 was removed from the analysis stage due to sound issues detected while recording the data, leaving 21 transcripts to analyze.

\section{RESULTS AND DISCUSSION}

In this section, we analyze three themes: 1) How BIM adoption might affect Green Star certification; 2) Barriers to using BIM to enhance Green Star certification; and 3) Solutions to using BIM to enhance Green Star certification. 
Table 1 Interviewee demographics

\begin{tabular}{|c|c|c|c|c|c|}
\hline Construction Position & $\begin{array}{l}\text { Experience } \\
\text { (years) }\end{array}$ & $\begin{array}{c}\text { Construction } \\
\text { Type }\end{array}$ & $\begin{array}{l}\text { Company } \\
\text { Size }\end{array}$ & $\begin{array}{c}\text { BIM } \\
\text { Projects }\end{array}$ & $\begin{array}{l}\text { Green Star } \\
\text { Projects }\end{array}$ \\
\hline Senior Quantity Surveyor & 10 & Contractor & Large & 1 & 1 \\
\hline BIM Manager \& GSAP $^{1}$ & 14 & Design & Large & $>50$ & 0 \\
\hline $\begin{array}{l}\text { Director, Building Scientist, } \\
\text { Green Star Assessor, \& GSAP }\end{array}$ & 12 & Consultancy & Large & $>50$ & 30 \\
\hline $\begin{array}{l}\text { Senior Architect, GSAP, } \\
\text { \& Green Star Assessor }\end{array}$ & 15 & Design & Large & 30 & $>45$ \\
\hline $\begin{array}{l}\text { Technical Services Manager, Design } \\
\text { Manager, GSAP, \& Green Star Assessor }\end{array}$ & 22 & Contractor & Large & 6 & 30 \\
\hline $\begin{array}{l}\text { 1) Director, Building Surveyor* } \\
\text { 2) Building Surveyor }\end{array}$ & $\begin{array}{c}14 \\
4 \\
\end{array}$ & Consultancy & SME & 15 & 0 \\
\hline Principal \& Designer & 30 & Design & SME & 4 & 3 \\
\hline Senior Cost Manager & 20 & Consultancy & Large & 1 & 2 (BREEAM) \\
\hline Project Director & 23 & Contractor & Large & 11 & 3 \\
\hline Building Services Technical Leader & 8 & Consultancy & Large & 7 & 1 \\
\hline Director \& Building Performance Expert & 19 & Consultancy & SME & 1 & 5 \\
\hline $\begin{array}{l}\text { 1) National BIM Manager* } \\
\text { 2) Building Scientist }\end{array}$ & $\begin{array}{c}22 \\
3 \\
\end{array}$ & Design & Large & $>50$ & 0 \\
\hline $\begin{array}{l}\text { 1) Associate \& Structural Engineer* } \\
\text { 2) Drawing Office Manager }\end{array}$ & $\begin{array}{l}10 \\
19\end{array}$ & Design & Large & $>50$ & 0 \\
\hline Structural Technician & 8 & Design & Large & 1 & 0 \\
\hline $\begin{array}{l}\text { Sustainability Leader, Green Star } \\
\text { Assessor, \& GSAP }\end{array}$ & 13 & Design & Large & $>50$ & 20 \\
\hline BIM Construction Manager & 11 & Contractor & Large & 40 & 0 \\
\hline $\begin{array}{l}\text { Technical Lead \& Senior Quantity } \\
\text { Surveyor }\end{array}$ & 12 & Multidiscipline & Large & $>50$ & 0 \\
\hline $\begin{array}{l}\text { BIM Consultant, Application Engineer, } \\
\text { \& Business Analyst }\end{array}$ & 17 & $\begin{array}{l}\text { Information } \\
\text { Technology }\end{array}$ & SME & $>50$ & 1 \\
\hline Associate Senior Architect & 11 & Design & Large & $>50$ & $\begin{array}{l}1 \text { (Green Star) } \\
1 \text { (Lotus) } \\
1\left(\text { PBRS }^{2}\right)\end{array}$ \\
\hline $\begin{array}{l}\text { 1) BIM Development Engineer* } \\
\text { 2) Senior Structural and Sustainable } \\
\text { Engineer, \& GSAP }\end{array}$ & $\begin{array}{c}20 \\
8\end{array}$ & Consultancy & Large & 50 & 3 \\
\hline Principal Quantity Surveyor & 8 & Multidiscipline & Large & 2 & 0 \\
\hline Green Star Assessor \& GSAP & 10 & Non-profit & Large & 0 & 45 \\
\hline
\end{tabular}

${ }^{1}$ Green Star Accredited Professional; ${ }^{2}$ Pearl Building Rating System; $*$ Corresponding interviewee

\subsection{How Could BIM Adoption Affect Green Star Certification?}

All interviewees were asked whether a relationship between BIM adoption and Green Star certification exists. Over half stated there is no current link between BIM and Green Star; however, 20 of them indicated that BIM adoption has the potential to assist in Green Star certification. Participant \#1, speaking about 6D BIM, stated, "The BIM model is linked to sustainability via 6D information where your Green Star credits are linked to the model. If you change a particular construction material, that will automatically update your Green Star credits." In the same vein, \#5 remarked, "They (construction practitioners) . . . linked the information into the model, so they just added the parametric data. All they have done is [take] pdfs with the information on the elements of the building. They have actually created the data fields in there, and they have actually populated all the information, so they click on the information here, populate them into the model, and they use the model as the repository of all of the information and using it ... it will make it easier to probably improve the schedule and get the output required for certification." "Potentially any information that Green Star needs can 
be held within the building information management workflow. So [there] could be any amount of information from concept design to construction to implementation and facility management, and Green Star can get that information from BIM" (\#13). "It is all the scheduling of properties on that ... There are lots of tables and evidence that you need to provide to show that you are compliant with Green Star, and a lot of them you can get from your model . . . it is easily [handed over] to the energy analysis guy for like the IES software and something like that, so that reduces the costs I suppose, and we do not need to rebuild the model. It just allows you to analyze stuff like shading, lighting, and so on" (\#19). "Green Star and modeling, outsourced modeling, dynamics thermal modeling, airflow modeling, daylight modeling, definitely this huge link is there, and that could get much stronger" (\#11). With BIM, \#16 remarked, "You could do all sorts of energy simulations and find the most optimum shape . . . they actually wrote a little script that just calculated sort of 200 to 400 different designs really quickly and then you can pick up the design that was the most energy efficient." As a result, BIM could help achieve a "better rating because you can analyze your projects much better in the early stages, so [it] probably allows you to have much better options with a great performance" (\#19). "What we are doing is . . . a manual process at the moment. We gather a lot of information, and then we start spreadsheeting and trying to prove it that way around. Whereas, if you are doing it systematically and building the mean to the model elements, particularly if we build families in models in Revit for instance, and we know the material that we want to use already has the information [captured] previously, we can reuse it. Once you get to the stage where you are reusing data, obviously you get the efficiencies because you put that element into the model and it has already got all the Green Star information in Revit" (\#5). According to \#17, "You could probably put the object properties within the model to see how many points you are going to be getting with each object; and then, once you have completed the model, hopefully, you can press a button, and it will tell you how many points your building is going to get." "In the end, if we want to determine Green Star credits on management, energy, waste, materials, location, and ecology, we can do all those things with [a] Revit file or IFC file" (\#16). "It should be possible to do your Green Star assessment almost purely by looking at the Revit model. Materials and your building services, all of that kind stuff, that [is] in there" (\#3).

The interviews reveal a crucial link between BIM adoption and Green Star certification. With BIM adoption, the process for Green Star certification is much shorter, easier, and more economical. These findings are consistent with the existing literature. Chen and Nguyen (2017) established a BIM-Web Map Service-Green Building framework to create a Revit-LEED plugin to optimize the green certification process for a location and transportation credits assessment. Bergonzoni et al. (2017) adopted BIM to develop an automatic calculation of indoor environmental quality for LEED assessments. In addition to LEED, BIM adoption offers potential advantages to other green building assessments such as BREEAM and BEAM Plus (Lu et al., 2017)

\subsection{Barriers to using BIM to Enhance Green Star Certification}

To gain a deeper understanding of the link between BIM and Green Star certification, interviewees were asked which factors stand in the way of a connection between the two.

A third of the interviewees believe BIM and Green Star certification processes are completely separate at the moment. According to \#5, "We are still actually applying information retrospectively or we still have the Green Star information here, the model information is there, they do not link," while \#2 asked, "As a designer, how can my design process marry up with the green process in a nice way? Instead . . . now I have two models and the assessment process." Meanwhile, \#10 emphasized BIM and Green Star are still in their early stages, "This is so new . . . it makes it hard to say if we want to do this, and we want to do that, and we want someone to manage both processes at the same time." 
A similar number of participants noted that a lack of client demand is a barrier to adoption. "How many projects out there in New Zealand [have] required BIM? How many projects [have] required Green Star? And how many for both?" asked \#11. This was also remarked by \#20 that "I do not think any of the projects we have been working on have had Green Star and BIM as a common focus."

The Green Star submission requirements, created by the NZGBC, are another challenge. "For the certification process, the assessments in the submission for Green Star [are] all currently based on, as you call it, traditional documentation, so they are 2D drawings, specifications, and thermal energy modeling. And because of what you are required to submit to NZGBC for assessments, there is no real advantage to a BIM project over . . . using 2D AutoCAD or something like that, because your documentation is assessed in the same way. By the time you print it to assess pdf drawings, [it] looks the same, whether it is a LOD (level of development) 300 BIM model or just a 2D AutoCAD model. So at the moment, there is not necessarily any advantage in terms of the green building assessment" (\#3). Another barrier to integration is low BIM maturity level or LOD. According to \#3, "People need to go to more than LOD 300. So if you start going to 400 or 500 , and you have all that sort of texture information in your BIM model, as you see it as that level 3, it is more than just the 3D spatial stuff, all the database, information but object-based evidence and something like that. When all that information is loaded in, it should, in theory, be possible to do your Green Star assessment almost purely by looking at the Revit model."

Other identified barriers include cost, industry capacity, a lack of knowledge, and the massive information requirements for the integration. Participant \#12 indicated that the problem is "understanding what information we need out of the model to provide the Green Star outputs, the same process around clients not understanding or being educated around BIM." "It is a combination of lacking awareness and costs, but I think it is more about the fear of costs, and the fear [of] what they do not quite understand" (\#14). Moreover, "To do all of this, you need a lot of information, a lot of information from a lot of people. So you need a large amount of information, you need a number of people to supply that information. Talking about the process from the design, I cannot give you the emissions because I do not know what the emissions are" (\#2). "Too much effort [is] required to do that kind of integration . . . most architects or engineers [are] like, it is just too much, and they just want to get the project done . . they probably input as little detail as possible just because it is not necessarily efficient for them to do it" (\#4). Last but not least, "What we do with Green Star at the moment is you [keep it] in your own files and email it around ... New Zealand we are quite a small country; it is a small NZGBC . . . the system as it is works fine. There might be a little bit more of time, but if you have got people to know what they are doing, it is not that much of a big deal" (\#22). Therefore, the idea of integrating BIM with Green Star is neglected.

Certain findings align with extant literature. Siddiqui et al. (2009) indicated that BIM and sustainable design are two separate processes occur during the building design currently. Lu et al. (2017) noted that a lack of experience and knowledge, and references the complexity of the green building assessment credits affect the BIM model. These require collaboration among stakeholders, a current barrier in the industry (Gandhi \& Jupp, 2014). Green Star submission requirements and industry capacity are two barriers unique to New Zealand, while the findings regarding a lack of client demand and the costs associating with BIM and Green Star certification have not been discussed in other studies.

\subsection{Solutions to using BIM to Enhance Green Star Certification}

After investigating the current barriers to using BIM to enhance Green Star certification, participants offered solutions that might minimize the problems. Half the interviewees felt the 
BIM and Green Star certification processes should be integrated. As noted by \#10, it should be possible to "find a good way to seamlessly link the processes and have BIM information transfer in the most optimal way using all of the technology that we have." "As soon as we can link that data, then you can see huge benefits in actually improving certifications, and because the administrative burden was one of the drawbacks of Green Star . . . this will drastically reduce that" (\#5). Specifically, \#11 suggested, "You can write an add-on for BIM that will do those things, or maybe you get some of the existing dynamics of modeling software [firms] to collaborate with the BIM [firms] and put them together."

The NZGBC should assume a more active role in integrating the Green Star certification process with BIM. They should "take on the whole digitizing [of] their processes, making the processes better, IT savvy and that kind of stuff" (\#2). "They would have to change all of their assessment processes" (\#3). Executing BIM properly first could also be considered a solution. "If you can get efficiencies from BIM then that would surely help to gain Green Star certification ... you are not actually duplicating work, you are not actually getting rid of a lot of material [because] if you have to do rework on site, it means you are going to have to demolish things and throw them away, which will have an impact on landfill and waste calculations, which have an impact on Green Star" (\#8). Participant \#4 highlighted "a need to get to a point where the model has enough detail"; "when all that information (required for the integration of BIM and Green Star) is loaded in, it should, in theory, be possible to do your Green Star assessment almost purely by looking at the Revit model" (\#3).

The NZGBC and stakeholders must collaborate to resolve these issues. Participant \#15 suggested, "The software development company needs to work with New Zealand Green Building Council" while \#17 stated, "Green Star as an organization would need to start setting up points for different objects, they would have to work with certain suppliers . . They would have to work with timber suppliers to work out. They are going to have to help the suppliers with their objects, with the materials, and give the rating, then maybe have these objects that have got certain points, and then they probably have to work with new suppliers to help them get their points." According to \#16, "It is very important for the team at some point to have a sort of kick-off and determine what we want to use the BIM model . . . if I want to do energy analysis, I have to make sure that maybe during the concept design phase that potentially the architect will model the facade in such a way that it is pretty accurate in geometry lines . . . the glass would have certain properties like the ETA value or the U value, etc., we can then do the energy analysis." "What you would probably do is [have] all of the parties involved in the Green Star certification working on one common data set that would all be in, that would be linked to the model. So any information that you did generate in your model would be exported ... whatever document or wherever the data stores that you got for Green Star, but I think most of the efficiency would be in having a common data environment for your Green Star information, making sure everyone was putting and removing information from that, making sure your models and your design information was linked to that kind of common data" (\#10).

Training in both BIM and Green Star certification can help resolve the problem, particularly "education and understanding about what they are, and how they come together" (\#7), which was recommended by most of the interviewees. Other solutions include showcasing benchmark projects and setting up a Green Star materials database. Interviewee \#1 asserted, "We might need to have some projects that [are] pioneers." "If we could prove [to] somebody that it works a certain way . . . a higher profile project might get a lot more attention" (\#14). Meanwhile, \#17 suggested, "Maybe you can put things within objects, so different objects within a model . . could actually probably put the object properties within the model to say how many points you are going to be getting with each object." For example, "I need a ceiling. If there is a list of [ceilings] ... the ceiling has Green Star credits of 10 points or whatever. It has a high point, and 
it has a reasonable price, so that means as a designer . . . instead of choosing from 100 ceilings, narrow[s] it down to 10 or 5 , and then I can choose . . . once I made my selection and my standard specification, if I can translate it to a green specification, that would be awesome" (\#2).

A few interviewees consider mandating BIM to be a good solution. Interviewee \#11 argued, "Mandating is probably going to be the fastest way to get the nation as a whole to have some experience of new things and therefore build up [a] story that supports its use ... I think mandating would be the fastest way to get uptake." Meanwhile, \#4 said, "If BIM is mandated, and it is a common standard, then you could see it (the integration of BIM and Green Star) and somehow manage to work with Green Star, there would be a benefit."

The interviewees made it clear that resolving the current barriers to linking BIM and Green Star certification requires integrating their processes. However, the New Zealand government and construction practitioners must also make an effort. Not only does the NZGBC need to optimize their Green Star certification process and actively consider adding BIM as an alternative approach, but the other stakeholders must engage with the NZGBC to establish a connection between BIM and Green Star certification. Furthermore, the government should create effective strategies to guide the construction industry as it continues to grow, such as mandating BIM for a certain type of project in New Zealand.

\section{CONCLUSION}

This paper examines the relationship between BIM adoption and Green Star certification. The results indicate that despite the absence of a current concrete connection, BIM adoption has the potential to ease Green Star certification. Information on Green Star credits could be linked to the BIM model, requiring only an add-on for the automatic assessment of Green Star certification. However, several challenges remain, including costs, industry capacity, information requirements, lack of knowledge, a lack of client demand, inflexible Green Star submission requirements, and low BIM maturity level or LOD. Solutions, arrived at with the help of the interviewed construction experts, include: (1) integrating BIM process with the Green Star certification process; (2) flexible Green Star submission requirements; (3) executing BIM properly; (4) collaboration among NZGBC and construction stakeholders; (5) providing education and training in both BIM and Green Star for clients and construction practitioners; (6) showcasing benchmark projects that use BIM to enhance Green Star certification; (7) setting up a Green Star materials database for BIM modeling; and (8) mandating BIM. This research contributes to the current knowledge of BIM and Green Star in New Zealand by providing baseline information to the NZGBC, construction stakeholders, and the government that allows for the formulation of effective strategies to be used to develop both BIM and Green Star. Future studies will determine how many Green Star credits that could be achieved by using BIM and how to integrate their processes.

\section{ACKNOWLEDGEMENT}

The authors are grateful to all the interviewees who participated in this study. This research is supported by the Vice Chancellor Doctoral Scholarship from Auckland University of Technology, New Zealand.

\section{REFERENCES}

Albrecht, W.D., 2011. LinkedIn for Accounting and Business Students. American Journal of Business Education, Volume 4(10), p. 39-42 
Auckland University of Technology, 2018. Applying for Ethics Approval: Guidelines and Procedures. Available Online at https://www.aut.ac.nz/research/researchethics/guidelinesand-procedures. Accessed on June 15, 2018

Bergonzoni, G., Capelli, M., Drudi, G., Viani, S., Conserva, F., 2017. Building Information Modeling (BIM) for LEED ${ }^{\circledR}$ IEQ Category Prerequisites and Credits Calculations. In: Proceedings of the $11^{\text {th }}$ European Conference on Product and Process Modelling (ECPPM 2016), Limassol, Cyprus, September 7-9, 2016

Bryde, D., Broquetas, M., Volm, J.M., 2013. The Project Benefits of Building Information Modelling (BIM). International Journal of Project Management, Volume 31(7), pp. 971-980

Chen, P.-H., Nguyen, T.C., 2017. Integrating Web Map Service and Building Information Modeling for Location and Transportation Analysis in Green Building Certification Process. Automation in Construction, Volume 77, pp. 52-66

Cohen, D., Crabtree, B., 2006. Qualitative Research Guidelines Project. Available Online at http://www.qualres.org/HomeEval-3664.html

Creswell, J.W., 2014. Research Design: Qualitative, Quantitative, and Mixed Methods Approaches. USA: Sage

Crouch, M., McKenzie, H., 2006. The Logic of Small Samples in Interview-based Qualitative Research. Social Science Information, Volume 45(4), pp. 483-499

Doan, D.T., Ghaffarianhoseini, A., Naismith, N., Zhang, T., Ghaffarianhoseini, A., Tookey, J., 2017. A Critical Comparison of Green Building Rating Systems. Building and Environment, Volume 123, pp. 243-260

Galvin, R., 2015. How Many Interviews are Enough? Do Qualitative Interviews in Building Energy Consumption Research Produce Reliable Knowledge? Journal of Building Engineering, Volume 1, pp. 2-12

Gandhi, S., Jupp, J., 2014. BIM and Australian Green Star Building Certification. Computing in Civil and Building Engineering, (CASCE 2014, pp. 275-282

Ghaffarianhoseini, A., Doan, D. T., Naismith, N., Tookey, J., Ghaffarianhoseini, A., 2017. Amplifying the Practicality of Contemporary Building Information Modelling (BIM) Implementations for New Zealand Green Building Certification (Green Star). Engineering, Construction and Architectural Management, Volume 24(4), pp. 696-714

Harrell, M.C., Bradley, M.A., 2009. Data Collection Methods: Semi-structured Interviews and Focus Groups. Santa Monica, CA: Rand National Defense Research Institute

Hurlimann, A.C., Browne, G.R., Warren-Myers, G., Francis, V., 2018. Barriers to Climate Change Adaptation in the Australian Construction Industry-impetus for Regulatory Reform. Building and Environment, Volume 137, pp. 235-245

Kvale, S., Brinkmann, S., 2009. InterViews: Learning the Craft of Qualitative Research Interviewing. SAGE Publications, Inc; $2^{\text {nd }}$ edition

Lu, Y., Wu, Z., Chang, R., Li, Y., 2017. Building Information Modeling (BIM) for Green Buildings: A Critical Review and Future Directions. Automation in Construction, Volume 83, pp. 134-148

Merriam, S.B., Tisdell, E.J., 2016. Qualitative Research: A Guide to Design and Implementation. $4^{\text {th }}$ Edition. San Francisco, CA: Jossey-Bass

Onwuegbuzie, A.J., Leech, N.L., 2005. On Becoming a Pragmatic Researcher: The Importance of Combining Quantitative and Qualitative Research Methodologies. International Journal of Social Research Methodology, Volume 8(5), pp. 375-387

Sacilotto, J., Loosemore, M., 2018. Chinese Investment in the Australian Construction Industry: The Social Amplification of Risk. Construction Management and Economics, Volume 36(9), pp. 1-14 
Schneiderman, K., 2016. Using Linkedin to Connect. Career Planning and Adult Development Journal, Volume 32(3), p. 32

Siddiqui, M.Z., Pearce, A.R., Ku, K., Langar, S., Ahn, Y.H., Jacocks, K., 2009. Green BIM Approaches to Architectural Design for Increased Sustainability. In: Symposium of the International Conference on Construction Engineering and Project Management, ICCEMICCPM

Sieber, S.D., 1973. The Integration of Fieldwork and Survey Methods. American Journal of Sociology, Volume 78(6), pp. 1335-1359 